DOI: $10.30519 /$ ahtr.527022

\begin{tabular}{lr}
\hline Advances in Hospitality and Tourism Research (AHTR) & 2019 \\
An International Journal of Akdeniz University Tourism Faculty & Vol. 7 (1) \\
ISSN: 2147-9100 (Print), 2148-7316 (Online) & $124-136$ \\
Webpage: http://www.ahtrjournal.org/ & \\
\hline
\end{tabular}

\title{
THE EFFECT OF INTERACTIVE IT TABLE SERVICE ON CONSUMER'S REVISIT INTENTION ${ }^{1}$
}

\author{
Amanda LIN \\ National Chin-Yi University of Technology, Taiwan \\ ORCID: 0000-0002-7767-0139 \\ Esther MA \\ National Chin-Yi University of Technology, Taiwan \\ ORCID: 0000-0002-8774-9596 \\ Brendan T. $\mathrm{CHEN}^{2}$ \\ National Chin-Yi University of Technology, Taiwan \\ ORCID: 0000-0002-9478-9019
}

\begin{abstract}
In the hospitality and catering industry, consumers are accustomed to face-to-face services, but the problems of Taiwan's aging society and the migration of manpower outward have become increasingly serious recently, impacting its service demands. In order to promote service quality and competitiveness and adapt to the global trends of industry technicalization, more and more scholars are thinking about the integration of innovative technological equipment or service modes for Taiwan's catering industry and exploring the impacts and effects of such integration. This study thus probed into the influences of the interactive table service on consumers' enjoyment of ordering and the revisit intention. It employed simple linear regression and verified if the hypothetical framework had a partial mediating effect. The results of this study demonstrated that consumers can gain pleasure by using a digital ordering machine, which affects their willingness to revisit. This study provides management implications and serves as a reference for future practitioners in terms of practice and for the academic community in terms of subsequent research.
\end{abstract}

\author{
Article History \\ Received 14 November 2018 \\ Revised 14 February 2019 \\ Accepted 14 February 2019
}

Keywords

hospitality

catering industry

interactive IT table service

enjoyment of ordering

1 An earlier version of this study was presented at the 8th Advances in Hospitality and Tourism Marketing and Management (AHTMM) conference, Bangkok, Thailand, June 2018.

2 Address correspondence to Brendan T. Chen, Department of Leisure Industry Management, National Chin-Yi University of Technology, Taichung, TAIWAN. E-mail: brendan@ncut.edu.tw 


\section{INTRODUCTION}

Most advanced countries in the world have entered an aged society with lower fertility rates. The proportion of the elderly has increased, while that of the working age population has declined. According to a study on Taiwan's population in 2016, the elderly accounted for $17.4 \%$, while the young population was $18.2 \%$ (Department of Statistics, Ministry of the Interior, 2016). Estimates have stated its total population would decrease by approximately $17 \%$ to $27 \%$ from 2016 to 2061 , resulting in a shortage of manpower (National Development Council, 2016). The United Nations Department of Economic and Social Affairs predicted that the proportion of working population (15-64 years old) in advanced countries such as the United States, Japan, and Germany would also gradually decline. According to the National Development Council, the proportion of labor force in Taiwan would fall from $74 \%$ in 2015 to $53 \%$ in 2055, and the number of working population would drop from 17.37 million in 2015 to 10.18 million (Chang, 2016). Take the catering industry for example, from the Data Center of the Ministry of Finance, the number of registered profit-making businesses has shown a growing trend year after year, from 106,287 in 2011 to 124,124 in 2015 (Hsieh, 2016). The above data indicate that Taiwan has entered an aging society, while its catering industry has flourished, resulting in a manpower shortage.

With the advance of science and technology, informatization has become a trend in the future. It is able to help reduce labor costs, improve the competitiveness of various industries, and introduce and utilize information systems. At present, industries in Taiwan are gradually replacing traditional manual services by science and technology-based systems. These are called the interactive table services meaning that consumers can consume without the help of service personnel. It is becoming an inevitable trend to combine automation and the catering industry. The digitalization of ordering helps enhancing operation performance and customer satisfaction.

This study therefore produced an electronic menu so that consumers can clearly understand all dishes, including ingredients and cooking methods. After ordering, relevant information is transmitted to the kitchen to reduce the time of meal preparation. When the kitchen finishes the dishes, service personnel receive alert prompts simultaneously so that they can serve freshly cooked dishes to customers quickly. More importantly, the digital ordering machine can remember consumers' dietary habits and preferences. Information on each visit of a customer is 
stored in a database. When the same customers visit next time, service personnel can clearly understand their needs so as to make them perceive whole-hearted services. Synchronization of information among the three parties and analysis of big data not only reduces errors, but also greatly improves service efficiency.

Industries in Taiwan are gradually replacing traditional manual services by science and technology-based systems so that consumers can consume without the need of service personnel. The characteristics and advantages of a digital ordering machine in the catering industry are that consumers directly contact the machine rather than service personnel for ordering, so that they can become more immersed in the atmosphere of a restaurant via such user-friendly machines. Furthermore, a machine has no emotion. In contrast, service personnel might have their service quality affected by their emotions. The catering industry is people-oriented, but it faces problems like shortage of manpower, increase in salaries, and high turnover rate. Service quality might be influenced by service personnel's stress and emotions. Past research studies tended to explore the impacts of willingness to engage practitioners on operation performance (Wang et al., 2012) as well as the benefits of modes and self-service technologies (SSTs) (Meuter et al., 2003). Most ordering machines in the past only had basic functions of ordering and checkout and were operated by service personnel. However, this study allowed consumers to operate the digital ordering machine by themselves and get information in a digital manner to see if, through such practice, they could learn dishes and ordering procedures. Due to the fun in ordering via such machine, consumers can become more immersed in the dining atmosphere of a restaurant and no longer need to rely on service personnel.

One of the main goals of this study was to investigate the consequent changes in the catering industry. For more clarification, further research questions can be listed are as follows.

(1) To investigate whether the digital ordering machine has a positive impact on consumers' fun in ordering.

(2) To investigate whether the digital ordering machine and consumers' fun in ordering have a positive impact on consumers' willingness of revisit.

(3) Serve as a reference for catering enterprises to innovate service models in the future, according to the research results. 
In the following sections, interactive IT table service on consumers' revisit intention model is developed based on the literature on interactive IT table service, enjoyment of ordering, and revisit intention; and the hypotheses that specify the directions of relationships among the constructs are proposed.

\section{LITERATURE REVIEW}

The first step for practitioners in the catering industry to increase the value of customers and maintain a sustainable business is to improve the quality of service. Nowadays, as technicalization becomes a trend, practitioners are introducing self-service electronic ordering systems to link internal and external service procedures. A digital ordering machine allows customers to learn detailed information on each dish and promotional products and facilitates them in making a decision on ordering. The technology experienced on-site and the consequent the enjoyment of ordering and fun attract customers to order and increase their desire of consumption.

\section{Interactive IT Table Service}

More functions of an ordering machine are expected to be developed in order to better serve customers. Most traditional ordering machines only have functions like ordering, serving, and checkout, and they are used by service personnel. The functions of such ordering machines are limited by the systematic functions offered by restaurants (Ahn \& Seo, 2018). Therefore, this study allowed consumers to operate a new digital ordering machine by themselves and to perceive the differences from machines in the past. This machine is operated by consumers rather than service personnel. The so-called self-service means that, without the direct help of service personnel, consumers can complete service activities on their own (Globerson \& Maggard, 1991). Today, Self-Service Technologies (SSTs) are replacing manual services in a traditional restaurant. Consumers use the Internet or interact with a machine to get the goods or services they need (Wang et al., 2012). They also pointed out that for consumers, when they ordered food by themselves, they could know the contents, nutrition, and price through the ordering system. Bitner et al. (2000) pointed out that, during self-service, consumers can generate spontaneous pleasure. For consumers, they see a drop in waiting time, benefit from efficient, flexible, 
and easy machines, experience a higher degree of customization (Meuter \& Bitner, 1998), and have fun in receiving science and technology-based services (Dabholkar, 1996). A self-service ordering system not only enables consumers to experience the fun of self-service and brings about other entertainment effects, but also increases the transmission speed and efficiency of services, reduces costs, and meets individual service needs (Seybold, 1998; Berry, 1999; Sindell, 2000). Fun in science and technologybased services can get closer to consumers (Wang, 2016).

\section{Enjoyment of Ordering}

For convenience and efficiency, many catering enterprises have introduced self-service ordering machines. Such machines not only speed up the efficiency of ordering, but also bring about more fun to consumers. Currently, many restaurants made changes to their ordering modes. They set up a tablet on each table, so consumers no longer need to wait for service personnel to take their order. Through the interactive machine, they can learn about dishes and order by themselves. The kitchen can receive ordering information in real time and start cooking. The time spent on the introduction of dishes and ordering is saved (Lo, 2014).

As the indoor positioning sensing system enjoys wider popularity, global researchers have noted that wireless network positioning, radio frequency identification (RFID) positioning, and passive RFID are being used to study robots for service. Such robots can be used in restaurants to provide basic services like ordering and delivering dishes to consumers (Yu et al., 2012). Wang et al. (2012) assumed that, through a self-service ordering system, consumers not only can learn about each dish, including ingredients, nutritional contents, and prices, but also enjoy the fun in using technological gadgets. Bitner et al. (2000) asserted that consumers are more pleasant during self-service. Consumers have fun in using science and technology-based services (Dabholkar, 1996). Hence, the integration of digital ordering machine systems with the catering industry not only reduces the time for introduction of dishes and ordering, but also adds fun to ordering. In summary, this study proposed the first hypothesis (H1).

H1: Interactive IT table service has a positive impact on enjoyment of ordering processing 


\section{Revisit Intention}

With the intensification of market competition, people in recent years have become more and more aware that customer relationship management is a key to the success of modern enterprises. First, in order to win in the competition of a modern market, restructuring is not enough. It is more important to win customers' recognition. The key to the success of an enterprise is to increase customers' willingness to revisit (Pullman \& Gross, 2004). Thus, science and technology have become a critical point in business innovation. Restaurant operators have increased their budgets in science and technology (Lorden \& Pant, 2016), as most customers prefer entertainment-oriented service scenarios. Practitioners can thus provide appropriate entertainment facilities to consumers to improve the latter's positive emotion and satisfaction (Wakefield \& Blodgett, 1994). Aside from whole-hearted services, restaurants can design activities and entertainments to bring about different surprises to customers, create more added value and drive customers' intention of consumption again (Hemmington, 2007). Wakefield and Blodgett (1994) held that the design of a set of activities or entertainments can enhance customers' positive emotions and repurchase intention. Thus, customers may revisit a restaurant, because of its self-service ordering machine. To sum up, this study proposed $\mathrm{H} 2$.

H2: Interactive IT table service has a positive impact on revisit intention.

Repurchase intention is a behavior that governs cognition and emotion. The more positive experience customers have, the more likely they will revisit a place or recommend it to others (Schoefer \& Diamantopoulos, 2008). Yalch \& Spangenberg (2000) found that, when experiencing positive emotions in a consuming place, customers are more likely to approach the place again. Therefore, it will be a future trend to introduce self-service ordering systems to the catering industry. Ahn \& Seo (2018) also deemed that it is becoming increasingly popular for restaurants to use digital ordering machines or intelligent electronic products to attract customers. Appropriate experience design can increase customers' loyalty (Pullman \& Gross, 2004). The more pleasant and satisfied consumers feel, the higher their willingness to revisit is (Wang et al., 2010). Successful entertainment experiences can create unique and unforgettable feelings to customers and achieve positive publicity through word of mouth (Pine \& Gilmore, 1998). Therefore, a digital ordering machine may bring about fun in ordering to consumers and increase their willingness to revisit. Hence, this study proposed H3 as follows: 
H3: Consumers having higher enjoyment on the ordering process will increase the impact of interactive IT table service on consumers' revisit intention.

\section{RESEARCH METHOD}

In response to global technicalization, Taiwan's catering industry is keeping up with international standards. As the working population recedes, people's demands for quality of life are increasing day by day. This study probed into the combination of the catering industry, science and technology in order to introduce new thinking into the ordering service to consumers of the catering industry. A digital ordering machine system can provide consumers with more convenient services, unify procedures, and increase consumer satisfaction. This study referred to the questionnaire of $\mathrm{Wu}$ et al. (2015) and explored if the digital ordering machine could influence consumers' fun in ordering and their willingness to revisit or if self-service directly affects consumers' willingness to revisit. See Figure 1 for the research framework and hypotheses proposed.

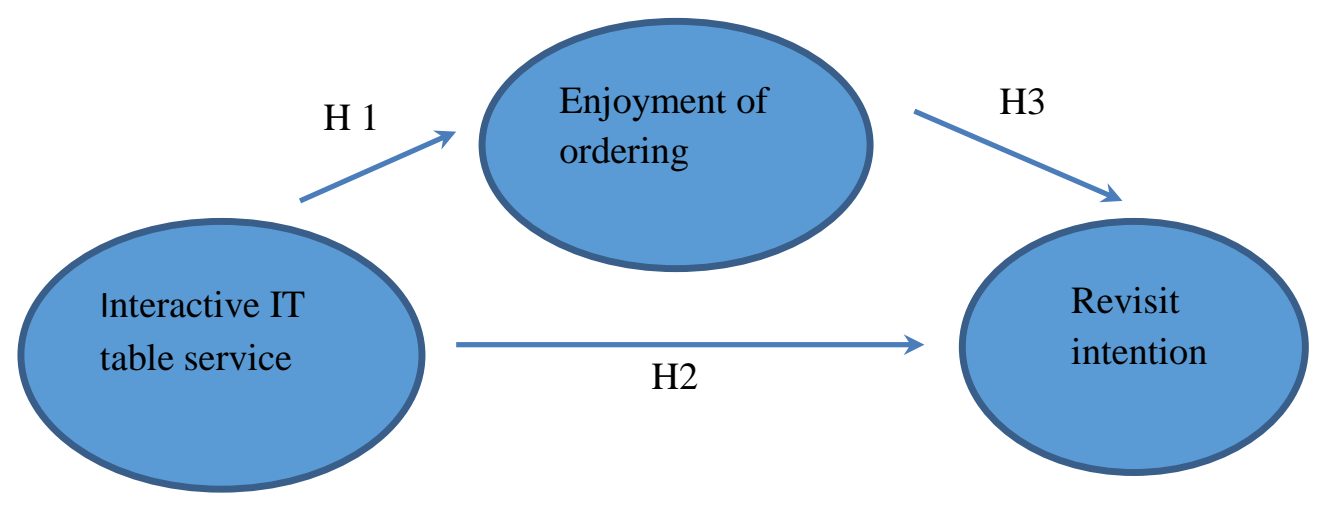

Figure 1. Research Framework

H1: Interactive IT table service has a positive impact on enjoyment of ordering processing.

H2: Interactive IT table service has a positive impact on revisit intention.

H3: Consumers having higher enjoyment on the ordering process will increase the impact of interactive IT table service on consumers' revisit intention. 


\section{Research Design}

This study utilized the customers of a steak house in Taichung City, Taiwan as its subjects. Every Saturday from June to November 2017, copies of a questionnaire were distributed onsite. An animal-like model was placed on each table. The model contained a tablet with ordering and voice systems. Whenever a customer wants to order, the tablet states, "Welcome! Which part of my body do you want to eat today?" The screen then displays different parts of a cow for customers to select. When customers order, their data are then sent directly to the kitchen. Dishes are prepared in order and delivered by service personnel. Through the user interface with rich images and the voice system, customers can order by themselves via the digital ordering machine. After completing the process in person, customers were asked to fill in the questionnaire. Total of 223 copies were distributed in this study. After recovery and screening, 207 copies were valid and used for analysis purposes.

\section{Verification of the Partial Mediating Effect}

This study adopted SPSS 20.0 to perform the statistical analysis of simple linear regression, to verify if the hypothetical framework had a partial mediating effect, if the hypotheses of this study were valid, and to check, based on the mediating effect, if the fun in ordering is a reason influencing consumers' use of the digital ordering machine. First, it considered the first 30 copies of the questionnaire as the target of the pre-test and verified if the questionnaire was reliable. It then predicted if the Cronbach's $\alpha$ value of the digital ordering machine to the fun in ordering was significant and then if the Cronbach's $\alpha$ value of the digital ordering machine to willingness to revisit was significant. Lastly, it simultaneously predicted if the Cronbach's $\alpha$ values of the digital ordering machine and fun in ordering to the willingness to revisit were significant. If the coefficient ability becomes smaller based on the comparison of the results with $\mathrm{H} 3$, then it means that the fun in ordering can predict the willingness to revisit in this model, and that it has a partial mediating effect and is a mediating variable that indirectly affects the willingness to revisit; otherwise, the fun in ordering has a complete mediating effect. 


\section{Reliability}

In order to confirm that each dimension corresponding to each item was consistent and stable, first, reliability analysis was conducted, and Cronbach's $\alpha$ values were used to measure reliability. Nunnally (1978) suggested that Cronbach's $\alpha$ should be greater than 0.7. This study measured the correlation of common factors among variables and calculated total and individual variances as the basis for the test of consistency. 30 copies of the questionnaire were used in the pre-test. As shown in Table 1, all their coefficient values were above 0.7. Then the reliability of all the questionnaires' copies was analyzed. As shown in Table 1, the coefficient values reached the standard required by the scholar, indicating that the questionnaire of this study has high internal consistency.

Table 1. Pre-Test and Post-Test Coefficient Values Dimension

\begin{tabular}{lll}
\hline & Pre-test $\alpha$ values & Post-test $\alpha$ values \\
\hline Enjoyment of ordering & 0.839 & 0.818 \\
Interactive IT table service & 0.757 & 0.848 \\
Revisit intention & 0.785 & 0.757 \\
\hline
\end{tabular}

\section{Partial mediating effect}

This study used simple linear regression analysis to test if fun in ordering is a mediating variable between digital ordering and willingness to revisit. Baron and Kenny (1986) presented that an independent variable that affects a third variable generated by a result variable is a mediating variable. The mediation effect stands for the effect of an independent variable on a dependent variable through a mediating variable (Hsiao, 2009). If a mediating variable can explain a part of an influence, then it is a partial mediating effect. If the correlation coefficient is significant, then it is a complete mediating effect.

\section{RESULTS}

\section{Regression analysis}

The first step predicted if the influence of digital ordering on revisit intention is significant (H1). As shown in Table 2, the standardized coefficient is 0.509 and $\mathrm{P}=0.000$. It thus reaches a significant level. The 
study then predicted if the influence of digital ordering on fun in ordering is significant $(\mathrm{H} 2)$. As shown in Table 3, the standardized coefficient is 0.495 and $P=0.000$. It also reaches a significant level. Lastly, it used digital ordering and fun in ordering to predict willingness to revisit at the same time (H3). It performed regression analysis to test if fun in ordering is a mediating variable. As shown in Table 4, the $\mathrm{P}$ value of digital ordering reaches a significant level, and the standardized coefficient is 0.288 . The coefficient is less than the result of $\mathrm{H1}$, implying that fun in ordering has a partial mediating effect.

Table 2. Regression Analysis for Interactive IT Table Service and Enjoyment of Ordering Relationship

\begin{tabular}{|c|c|c|c|c|c|}
\hline Model 1 & $\begin{array}{c}\text { standardized } \\
\text { coefficient }\end{array}$ & $t$ & Significant & $R$ & $\triangle R^{2}$ \\
\hline & $\beta e t a$ & & & & \\
\hline ( constant ) & - & 4.833 & 0.000 & 0.259 & 0.255 \\
\hline Interactive IT table service & 0.509 & 8.461 & 0.000 & & \\
\hline
\end{tabular}

Table 3. Regression Analysis for Interactive IT Table Service and Revisit Intention Relationship

\begin{tabular}{|c|c|c|c|c|c|}
\hline Model 2 & $\begin{array}{c}\text { standardized } \\
\text { coefficient }\end{array}$ & $t$ & Significant & $R^{2}$ & $\triangle R^{2}$ \\
\hline ( constant ) & - & 8.491 & 0.000 & \multirow[b]{2}{*}{0.245} & \multirow[b]{2}{*}{0.241} \\
\hline $\begin{array}{l}\text { Interactive IT } \\
\text { table service }\end{array}$ & 0.495 & 8.151 & 0.000 & & \\
\hline
\end{tabular}

Table 4. Regression Analysis for Mediating Relationship

\begin{tabular}{|c|c|c|c|c|c|}
\hline \multirow[t]{2}{*}{ Model 3} & $\begin{array}{c}\text { standardized } \\
\text { coefficient }\end{array}$ & \multirow[t]{2}{*}{$t$} & \multirow[t]{2}{*}{ significant } & \multirow[t]{2}{*}{$R^{2}$} & \multirow[t]{2}{*}{$\triangle R^{2}$} \\
\hline & $\beta e t a$ & & & & \\
\hline ( constant ) & - & 0.973 & 0.332 & \multirow{3}{*}{0.409} & \multirow{3}{*}{0.403} \\
\hline $\begin{array}{l}\text { Interactive IT } \\
\text { table service }\end{array}$ & 0.288 & 4.653 & 0.000 & & \\
\hline $\begin{array}{c}\text { Enjoyment of } \\
\text { ordering }\end{array}$ & 0.446 & 7.198 & 0.000 & & \\
\hline
\end{tabular}




\section{DISCUSSION AND CONCLUSION}

Customers were captivated by the process of ordering their food digitally. The touch screen, ordering functions, greetings, and digital machine operations contributed to a memorable and unique experience. These findings correspond to those of Bitner et al. (2000), who deemed that consumers were pleased during self-service and also those of Dabholkar (1996), who thought that consumers enjoyed science and technology-based services. Therefore, the integration of digital ordering machine systems into the catering industry can drastically improve efficiency and entertainment to the ordering procedure. In addition, the results showed an increase in customer's willingness to revisit due to the implementation of the digital ordering machine. This observation is consistent with Wakefield and Blodgett (1994) who designed a set of activities/ entertainments for customers to participate in, feel positive emotions, and raise repurchase intention.

The subjects of this study were randomized customers from a steak house in Taichung City, Taiwan. This study serves as a reference for scientific and technological innovation in the catering industry. It allowed consumers to operate a new digital ordering machine by themselves. This machine is different from the traditional personal digital assistant (PDA) that can only be operated by service personnel. The animal-like model and design of greetings raised consumers' intimacy and provided an unforgettable dining experience.

This study reviewed the relevant literature, established a theoretical framework, and summarized its results. In addition, it offers the following contributions to the managers. In the recreation and tourism industry, although there are many theories related to the catering industry, few papers have discussed the impact of digital ordering on the catering industry. Therefore, this study thoroughly explored the interactive IT table service, enjoyment of ordering, and intention to revisit. It obtained results based on the data of partial mediating effect that can serve as a reference for future research. This study proposed and analyzed research questions. It discovered some of the positive effects (increasing customer revisitation, order efficiency, and etc.) with regards to ordering meals via the interactive IT table service. Consumers are more pleasant during selfservice when they have fun in using science and technology-based services. This result is conducive for practitioners in the catering industry to set up appropriate business guidelines. 
The limitations of this study only focused on one steak house in Taichung, which found it easy to apply the digital ordering machine. It regarded young people as the majority of its research subjects. After operating the digital ordering machine, consumers were asked to fill in a questionnaire. This study only classified consumers by gender, failing to explore the interaction between the digital ordering machine and service personnel.

It is suggested that follow-up scholars can expand the scope to restaurants in Taiwan equipped with an interactive IT table service, learn the needs of a digital catering machine by consumers of different age groups, and design more functions in line with consumers' needs. Furthermore, they can go more in depth on the positive/negative impacts of a digital ordering machine on service personnel and restaurants. For example, how does the operation of a digital ordering machine by consumers affect a restaurant's serving efficiency, revenue and cost, as well as the pressure placed upon service personnel?

\section{REFERENCES}

Ahn, J. A., \& Seo. S. B. (2018). Consumer responses to interactive restaurant self-service technology (IRSST): The role of gadget-loving propensity. International Journal of Hospitality Management, 74, 109-121.

Baron, R. M., \& Kenny, D. A. (1986). The moderator-mediator variable distinction in social psychological research: Conceptual, strategic, and statistical considerations. Journal of Personality and Social Psychology, 51(6), 1173-1182.

Berry, L. L. (1999). Discovering the Soul of Service. New York: Free Press.

Bitner, M. J., Brown, S. W., \& Meuter, M. L. (2000). Technology infusion in service encounters. Journal of the Academy of Marketing Science, 28(1), 138149. https://doi.org/10.1177/0092070300281013

Chang, J. H. (2016). Development status and trend of commercial robots. Institute for Information Industry. Retrieved November 19, 2016, from http://www.nspark.org.tw/documentlibrary/view/248/19_Doc_20160908150354.p $\mathrm{df}$

Dabholkar, P. A. (1996). Consumer evaluations of new technology-based self-service options: An investigation of alternative models of service quality. International Journal of Research in Marketing, 13(1), 29-51.

Globerson, S., \& Maggard, M. J. (1991). A conceptual model of selfservice, International Journal of Operations \& Production Management, 11(4), 3343, https://doi.org/10.1108/01443579110002977

Hemmington, N. (2007). From service to experience: Understanding and defining the hospitality business. The Service Industries Journal, 27(6), 747-755.

Hsiao, W. L. (2009). The practical book of introduction to multivariate analysis. Taipei: GOTOP.

Nunnally, J. C. (1978). Psychometric theory (2nd ed.). New York: McGrew-Hill. 
Hsieh, Y. J. (2016). Industry Analysis: The development trend in the catering industry. Taiwan Trend Research, Retrieved November 19, 2016, from http://www.twtrend.com/share_cont.php?id=51

Lo, Z.H. (2014). The first restaurant in Yasukuni, Japan's fixed food chain, is equipped with a tablet and a buffet. Retrieved November 19, 2016, from http://www.ithome.com.tw/news/91881

Meuter, M. L., \& Bitner, M. J. (1998). Self-service technologies: extending service frameworks and identifying issues for research. Paper presented at the American Marketing Association. Conference Proceedings.

Meuter, M. L., Ostrom, A., Bitner, M. J., \& Roundtree, R. (2003). The influence of technology anxiety on consumer use and experiences with self-service technologies. Journal of Business Research, 56(11), 899-906.

Ministry of the Interior Department of Statistics (2016). Ministry of the Interior Department of Statistics reported in the third week of 2016, 2016/10/15 Retrieved November 11, 2016, from http://www.moi.gov.tw/stat/ news_content.aspx?sn=10225\&page=3

National Development Council (2016). The Republic of China population estimate (2016 to 2061 years), the first edition of the Republic of China in August 105, the first brush.

Pine, B. J., \& Gilmore, J. H. (1998). Welcome to the Experience Economy. Harvard Business Review, 76, 97-105.

Pullman, M. E., \&Gross, M. A. (2004). Ability of experience design elements to elicit emotions and loyalty behaviors. Decision Sciences, 35(3), 551-578.

Schoefer, K., \&Diamantopoulos, A. (2008). Measuring experienced emotions during service recovery encounters: Construction and assessment of the ESRE scale. Service Business, 2, 65-81.

Seybold, P.B. (1998). Customers.com: How to Create a Profitable Business Strategy for the Internet and Beyond. New York: Crown Business.

Sindell, K. (2000). Loyalty Marketing for the Internet Age: How to Identify, Attract, Serve, and Retain Customers in an E-commerce Environment. Chicago: Dearborn Financial Publishing.

Wakefield, K., \& Blodgett, J. G. (1994). The importance of services capes in leisure service settings. Journal of Services Marketing, 8(3), 66-76.

Wang, S., Tsai, C. Y., \&Chu, Y. C. (2010). Tourist behavior in Hakka Cultural Parks. African Journal of Business Management, 4(14), 2952-2961.

Wang, J.H., Cheng, C. C., \&Hsu, J. L. (2012). A study on the acceptance and operating performance of self-service electronic ordering service for catering industryintegrating views of the customers and operators. Journal of Performance and Strategy Research, 9(1), 63-84.

Wang, Y. (2016). The first Taiwanese remote robot clerk punched the card to work. Chinese DIGITIMES, 2016/11/25 Retrieved November 19, 2016, from http://www.chinatimes.com/realtimenews/20160825004860-260410

Wu, W. C. V.; Wang, R. J.; Chen, N. S. (2015). Instructional design using an in-house built teaching assistant robot to enhance elementary school English-as-a-foreign language learning. Interactive Learning Environments, 23(6), 696-714.

Yalch, R. F., \& Spangenberg, E. R. (2000). The effects of music in a retail setting on real and perceived shopping times. Journal of Business Research, 49(2), 139-147.

Yu, Q., Yuan, C., Fu, Z., \& Zhao, Y. (2012). An autonomous restaurant service robot with high positioning accuracy. Industrial Robot: An International Journal, 39(3), 271-281. 